\title{
MITOLOGI DAN SAINS: Bledug Kuwu di Kabupaten Grobogan
}

\author{
Aninditia Sabdaningsih \\ Research Fellow \\ Tropical Marine Biotechnology Laboratory Diponegoro University \\ Departemen Sumberdaya Akuatik, Universitas Diponegoro \\ Jl. Prof. H. Soedarto, SH, Tembalang Semarang 50275 \\ Email: aninditia@gmail.com
}

\begin{abstract}
Bledug Kuwu is a unique mud volcano phenomenon located at Kuwu, Kradenan district, Grobogan Regency, Central Java. This area is far away from marine environment; however, this area contains high salinity hence none of plant and animal can live on this area. People believe about myth of arising mud volcano comes from the point where Joko Linglung, a giant snake, exit and enter the earth. Science has revealed about the origin of Bledug Kuwu and its potential. In this paper, Bledug Kuwu will be described from the local myth and multidisciplinary sciences.
\end{abstract}

Key words: Bledug Kuwu, Grobogan, mud volcano, myth, science.

\section{Pendahuluan}

Bledug Kuwu merupakan sebuah fenomena gunung api lumpur (mud volcano) yang terletak di Desa Kuwu, Kecamatan Kradenan, Kabupaten Grobogan (van Bemmelen, 1949). Asal mula dinamakan Bledug Kuwu dikarenakan letupan bunyi "Bledug" (seperti suara meriam dari kejauhan) yang terjadi di desa Kuwu. Kawasan seluas 45 hektar ini sangat unik dan merupakan salah satu objek wisata andalan Kabupaten Grobogan. Bledug Kuwu secara geografis terletak di dataran rendah dengan suhu $28-36^{\circ} \mathrm{C}$ yang mengeluarkan gelembung lumpur secara periodik dan berpindah-pindah, lumpur tersebut bercampur gas, air, uap dan garam. Gelembung lumpur ini akan semakin kuat ledakannya saat sore, menurut pemandu yang ada di lokasi, hal ini disebabkan Laut Selatan sedang pasang. Wilayah ini memiliki kadar garam yang tinggi dan tidak terdapat tumbuhan maupun hewan yang hidup pada lokasi tersebut, kecuali rumput dan burung blekok (Ardeola palloides) yang hanya ditemukan di pinggiran lokasi. Di luar kawasan Bledug Kuwu sudah tidak ditemukan keunikan lagi, sumur yang digunakan oleh penduduk sekitar tidak terasa asin.
Masyarakat sekitar masih mempercayai bahwa Bledug Kuwu terjadi disebabkan oleh bekas keluar masuknya Joko Linglung, ular raksasa anak Prabu Aji Saka yang melintas dari dalam bumi yaitu dari Laut Selatan untuk kembali ke Medhang Kamulan setelah mengalahkan buaya putih jelmaan Dewata Cengkar. Ritual adat seperti tirakatan pun masih sering dilakukan oleh masyarakat sekitar untuk mencari keberkahan. Namun seiring dengan perkembangan ilmu pengetahuan, penelitian mengenai Bledug Kuwu mulai banyak dilakukan untuk mendapatkan kebenaran secara sains. Beberapa ahli telah mengkaji Bledug Kuwu dari berbagai disiplin ilmu.

Artikel ini membahas mengenai Bledug Kuwu dari segi mitologi yang mencakup legenda dan ritual yang diselenggarakan dan dari segi sains meliputi bidang geofisika, geologi, geomatika, palaentologi, mikrobiologi, biokimia, molekuler dan kimia.

\section{Kabupaten Grobogan}

\section{1. Sejarah}

Kabupaten Grobogan merupakan kabupaten yang sudah dikenal sejakmasa kerajaan Mataram Hindu. Hari jadi Kabupaten Grobogan adalah 4 Maret 1726, 
saat ini telah berusia 289 tahun. Daerah ini menjadi pusat Kerajaan Mataram dengan ibu kotanya di Medhang Kamulan atau SuMedhang Purwocarito atau Purwodadi. Pada masa kerajaan Medhang dan Kahuripan, daerah Grobogan merupakan daerah yang penting bagi negara tersebut, sedang pada masa Majapahit, Demak, dan Pajang, daerah Grobogan selalu dikaitkan dengan cerita rakyat $\mathrm{Ki}$ Ageng Sela, Ki Ageng Tarub, Bondan Kejawan dan cerita Aji Saka. Pada masa kerajaan Mataram Islam, daerah Grobogan termasuk Daerah Mancanegara dan pernah menjadi wilayah koordinatif Bupati Nayoko Ponorogo Adipati Surodiningrat. Dalam masa Perang Prangwadanan dan Perang Mangkubumen, daerah Grobogan merupakan daerah basis kekuatan Pangeran Prangwedana (RM Said) dan Pangeran Mangkubumi. Dalam pekembangan sejarah selanjutnya, atas ketentuan Perjanjian Giyanti pada tahun 1755, sebagai wilayah Mancanegara, Grobogan termasuk wilayah Kasultanan bersama-sama dengan Madiun, separuh Pacitan, Magetan, Caruban, Jipang (Bojanegara), Teras Karas (Ngawen), Sela, Warung (Kuwu-Wirosari) (Soekanto, 1958).

Berdasarkan isi dan pola penyajian, yang bersumber pada Serat Sindula atau serat Babad Pajajaran Kuda Laleyan dan Serat Witoradyo, cerita Aji Saka merupakan cerita legendaris, tentang kepahlawanan seorang tokoh dalam lingkup Budaya Jawa (Raffles, 1917, 1930). Di lain pihak cerita Aji Saka di daerah Kabupaten Grobogan juga merupakan cerita mitologis, yaitu cerita yang bersangkut paut dengan kepercayaan asli masyarakat. Oleh karena itulah maka penyajian cerita Aji Saka diciptakan dalam bentuk cerita "lambang" bagi penetrasi budaya Hindu di Jawa.

Cerita Aji Saka dapat dikelompokkan sebagai cerita yang mengandung unsurunsur mesianis, yaitu karya penyelamatan umat manusia dari kehancuran. Aji Saka sebagai Mesias menghancurkan penguasa kejam: Dewata Cengkar. Berdasarkan beberapa referensi dari sumber tradisional di antaranya Serat-serat Jawi Ingkang Tanpa Sekar, Primbon Jayabaya, Serat Jangka
Jagad, dan Serat Witoradyo III diketahui bahwa Aji Saka adalah seorang raja yang kemudian meninggalkan tahta kerajaannya dan menjadi seorang Brahmana. Berarti dia adalah penganut agama Hindu, sebab sebutan untuk Brahmana adalah untuk penganut agama Hindu. Brahmana bagi agama Budha disebut sebagai bhiksu. Tetapi dari data historis tokoh Aji Saka tidak pernah ada (hidup). Dengan demikian tokoh ini merupakan tokoh bayangan. Dia diadakan untuk menunjukkan adanya pengaruh Hinduisme dalam masyarakat Jawa. Kebetulan pada waktu itu keadaan masyarakat Medhang Kamulan sedang resah. Kesempatan ini digunakan oleh Aji Saka (baca umat Hindu) untuk menyebarkan agama Hindu di masyarakat Medhang Kamulan. Hal ini dikiaskan dalam lambang "desthar" (ikat kepala), yang menjadi tradisi Jawa, menggunakan ikat kepala. Sedang kepala adalah tempat otak, pikir, nalar: di dalam otak itulah tersimpan segala macam ilmu pengetahuan manusia. Ikat kepala tadi ketika ditebarkan (dijereng) dapat menutupi seluruh Wilayah Medhang Kamulan. Di sinilah pengikut Prabu Dewata Cengkar harus mengakui kekalahan berebut pengaruh, dan harus menyingkir dari negeri Medhang (dikiaskan dengan menyeburkan diri ke laut menjadi seekor buaya putih).

\section{2. Keadaan Alam}

Kabupaten Grobogan yang memiliki relief daerah pegunungan kapur dan perbukitan serta dataran di bagian tengahnya, secara topografi terbagi ke dalam 3 kelompok sebagai berikut.

(1). Daerah dataran rendah berada pada ketinggian sampai 50 meter di atas permukaan air laut dengan kelerengan 00-80 yang meliputi 6 kecamatan yaitu Kecamatan Gubug, Tegowanu, Godong, Purwodadi, Grobogan sebelah selatan dan Wirosari sebelah selatan.

(2). Daerah perbukitan berada pada ketinggian antara 50-100 meter di atas permukaan air laut dengan kelerengan 80150 yang meliputi 4 kecamatan yaitu Kecamatan Klambu, Brati, Grobogan sebelah utara dan Wirosari sebelah utara. 
(3). Daerah dataran tinggi berada pada ketinggian 100-500 meter di atas permukaan air laut dengan kelerengan lebih dari 150, meliputi wilayah kecamatan yang berada di sebelah selatan dari wilayah Kabupaten Grobogan.

Berdasarkan letak geografis dan reliefnya, Kabupaten Grobogan merupakan Kabupaten yang tiang penyangga perekonomiannya berada pada sektor pertanian dan merupakan daerah yang cenderung cukup sulit mendapatkan air bersih (www.grobogan.go.id).

\section{3. Letak Geografis Bledug Kuwu}

Bledug Kuwu terletak di Desa Kuwu, Kecamatan Kradenan, Kabupaten Grobogan,
Provinsi Jawa Tengah, dapat ditempuh kurang lebih $28 \mathrm{~km}$ ke arah timur dari Kota Purwodadi. Lokasi Bledug Kuwu dapat dilihat juga dengan menggunakan Google Earth pada koordinat $7^{\circ} 07^{\prime} 03.90^{\prime \prime} \mathrm{LS}$, $111^{\circ} 07^{\prime} 17.61^{\prime \prime B T}$ (Gambar 1). Objek wisata yang menyajikan keajaiban alam ini luasnya \pm 45 hektar. Kawasan wisata yang secara geografis terletak di dataran rendah bersuhu $28-36^{\circ} \mathrm{C}$ ini menyajikan letupan gelembung lumpur raksasa yang mengeluarkan percikan air dan garam. Letupan-letupan tersebut terjadi setiap saat dan berpindah-pindah tempat dengan diikuti asap putih yang menimbulkan aroma belerang (Giwangkara, 2006).

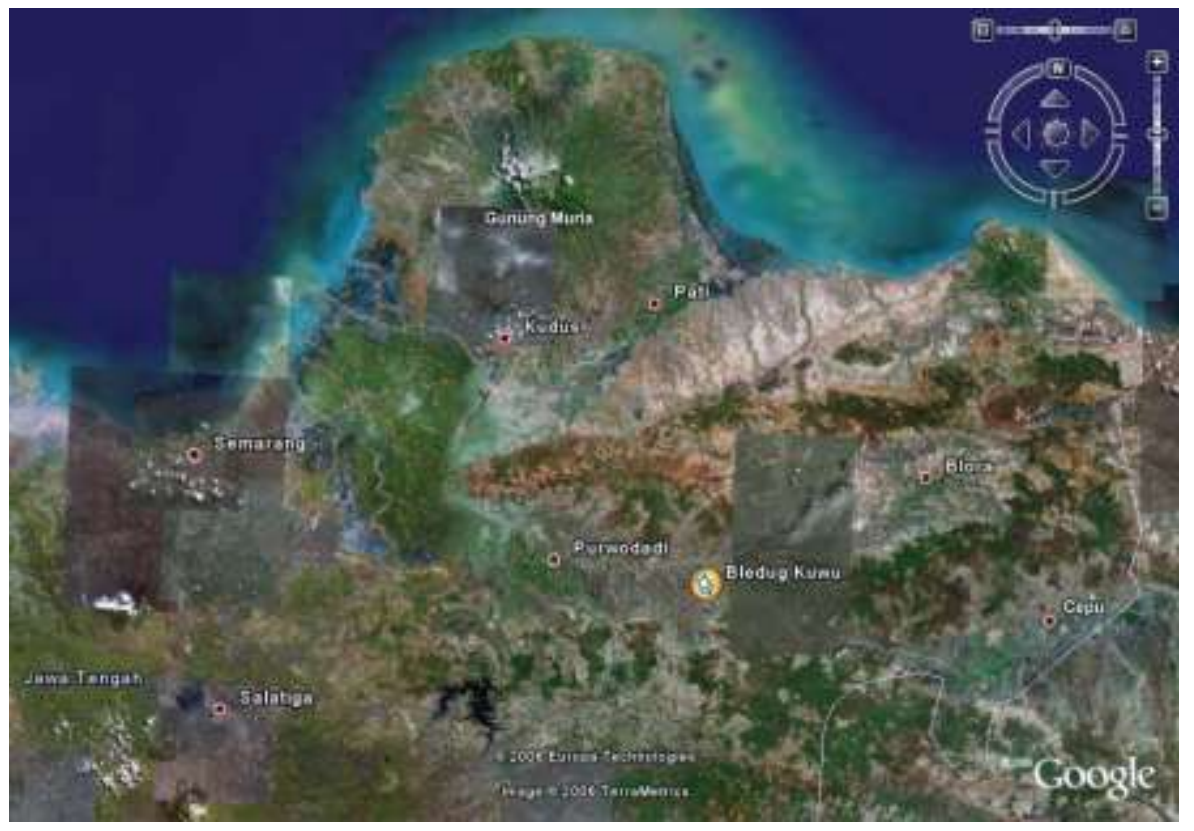

\section{4. Bledug Kuwu Secara Mitologi}

\section{4. 1. Legenda}

Di sebuah desa, tinggal sebuah keluarga Kaki Grenteng, Nyai Grenteng dan anak perempuannya Roro Cangkek. Suatu ketika, Roro Cangkek menyimpan beberapa telur ayam yang di antaranya memiliki ukuran yang lebih besar daripada umumnya. Telur tersebut disimpan di lumbung padi. Saat Kaki Grenteng membongkar lumbung dikarenakan tumpukan padinya tak pernah habis, ia terkejut melihat ada kepala ular raksasa yang dapat berbicara seperti manusia. Seisi rumah terkejut, Nyai Grenteng dan Roro Cangkek pun sempat pingsan, saat Roro Cangkek sadar dan melihat wajah ular raksasa tersebut mengingatkannya pada Aji Saka. Ular tersebut memanggil Roro Cangkek ibu dan bermaksud mencari Aji Saka yang diakuinya sebagai ayah. Begitu ular tersebut diberi tahu bahwa Aji Saka menjadi seorang raja di Medhang Kamulan, si ular undur diri dan langsung menghadap ke istana. Prajuritprajurit istana digemparkan oleh wujud ular raksasa dan melapor kepada Prabu Aji Saka, dikarenakan ular tersebut dapat berbicara dan ingin menemui sang Raja, akhirnya Prabu Aji Saka menghampiri ular tersebut dan menanyakan asal usulnya. Si ular 
meyakinkan bahwa dirinya adalah putra kandung Aji Saka, sang Prabu marah dan tidak percaya bagaimana bisa seorang manusia mempunyai anak seekor ular, sang Prabu pun belum menikah. Ular pun menceritakan bahwa dulu sang Prabu pernah singgah di rumah Kaki Grenteng, setelah bertemu dengan Roro Cangkek, sang Prabu membuang hajat, kebetulan ada ayam jago yang meminumnya, ayam jago tersebut bertelur dan telurnya disimpan oleh Roro Cangkek, lahirlah si ular. Aji Saka hanya akan mengakui ular tersebut sebagai anak dengan syarat dapat membunuh buaya putih di Samudera Selatan (Laut Kidul) yang menjadi musuh berbahaya bagi rakyat Medhang Kamulan dan harus kembali ke Medhang Kamulan lewat dasar bumi, jika tidak berhasil rakyat akan membunuh si ular. Ular raksasa ini lalu menghilang bagai kilat menuju Samudera Kidul, si Buaya putih yang sedang berjemur di tepi pantai seketika diserang oleh ular raksasa. Terjadi pertempuran yang sengit antara kedua binatang tersebut, namun akhirnya buaya putih dapat dililit sekujur tubuhnya dan direndamkan ke dalam air sampai menghembuskan nafas terakhir, kepala buaya ditelan untuk dibawa ke hadapan sang Prabu Aji Saka (Anonim, 2015).

Perjalanan ular raksasa itu untuk pulang ke Medhang Kamulan dari dalam bumi ternyata tak mudah. Perjalanan yang dianggapnya sudah jauh, membuat sang ular raksasa ingin melihat keadaan luar bumi. Kemunculan pertama ular raksasa tersebut terjadi di Desa Jono Kecamatan Tawangharjo Kabupaten Grobogan. Sampai saat ini daerah ini dikenal sebagai daerah penghasil bleng dan dapat diproses menjadi garam dapur; kemunculan kedua di Desa Crewek; dan pada kemunculan ketiga, ia sudah tidak tahan lagi, dan dengan seluruh kekuatannya ia mengangkat seluruh badannya ke luar. Tempat ketiga inilah dikenal dengan nama Bledug yang berada di Desa Kuwu, Kecamatan Kradenan. Keajaiban terjadi di sini, tubuh ular raksasa menyusut lalu menjadi seorang anak kecil yang lumpuh. Seorang dukun bayi yang melintas melihat keadaan tersebut lalu diurutlah si anak hingga kesehatannya pulih, dan diberi nama Joko Linglung. Tempat ini berada di pojok timur laut yang masih satu lokasi dengan Bledug Kuwu, dikeramatkan oleh masyarakat setempat dan dijaga oleh empat juru kunci. Pada tanggal 1 sampai 9 Syuro, banyak yang melakukan tirakatan sambil mengerjakan sholat malam, memohon berkah dari Allah S.W.T. Joko Linglung lalu berpamitan untuk melanjutkan perjalanannya menuju Medhang Kamulan, ia menjelma kembali menjadi seekor ular raksasa dan masuk ke lubang di depannya. Lubang bekas masuknya Joko Linglung tak lama kemudian penuh berisi lumpur yang disusul suara bledug sampai saat ini (Anonim, 2015).

\section{4. 2. Ritual}

Berdasarkan hasil wawancara dengan juru kunci Bledug Kuwu, diperoleh informasi bahwa unsur magis di Bledug Kuwu masih kental dan dipercaya memberi keberuntungan bagi orang-orang yang mempercayai mitos. Ritual biasanya dilakukan pada hari Kamis atau Jumat. Ritual adat tersebut dilakukan dengan tujuan untuk memperoleh keselamatan dan beberapa pengunjung mempercayai bahwa dengan membawa sesajen yang telah ditentukan maka keinginannya akan dikabulkan oleh para leluhur yang mendiami Bledug Kuwu. Adapun sesajen yang diperlukan adalah pisang raja satu sisir untuk laki-laki dan pisang kawista untuk perempuan, bunga setaman, kapur sirih, dan air putih. Pengunjung yang melakukan ritual biasanya memiliki keinginan untuk memperoleh jabatan ataupun kekuasaan; mereka datang dari berbagai kota dan negara (Sugiyo, 2015).

\section{5. Bledug Kuwu Secara Sains}

\section{5. 1. Geofisika}

Penelitian geofisika di Bledug Kuwu dilakukan oleh Indriana et al. (2007) dengan menggunakan metode Self Potential. Penelitian ini bertujuan untuk mengetahui distribusi nilai potensial diri, nilai kedalaman dan sudut polarisasi sumber potensial diri (anomali) di Bledug Kuwu 
berdasarkan persebaran nilai isopotensialnya sehingga dapat menambah informasi geologi yang dibutuhkan untuk memprediksi struktur bawah permukaan di daerah Bledug Kuwu dan sekitarnya yang berhubungan dengan indikasi adanya laut purba.

Hasil penelitian menunjukkan bahwa dari peta kontur isopotensial (Gambar 2) dapat diinterpretasi beberapa anomali yang terdapat di sebelah barat dan timur yaitu di lokasi 2 Bledug besar dan sebelah tenggara Bledug besar 2. Nilai isopotensial berada pada nilai $-320 \mathrm{mV}$ sampai $20 \mathrm{mV}$. Pada daerah anomali yaitu pada daerah letupan besar nilai potensialnya $-140 \mathrm{mV}$ sampai dengan $-160 \mathrm{mV}$. Di antara 2 Bledug nilai potensialnya paling tinggi yaitu $0 \mathrm{mV}$. Dari kontur dapat dianalisis bahwa nilai potensial makin kecil ke arah Bledug. Nilai potensial yang sangat kecil mengindikasikan daerah Bledug adalah daerah yang konduktif (Indriana et al., 2007).

\section{Gambar 2. Data Lapangan Kontur Isopotensial}

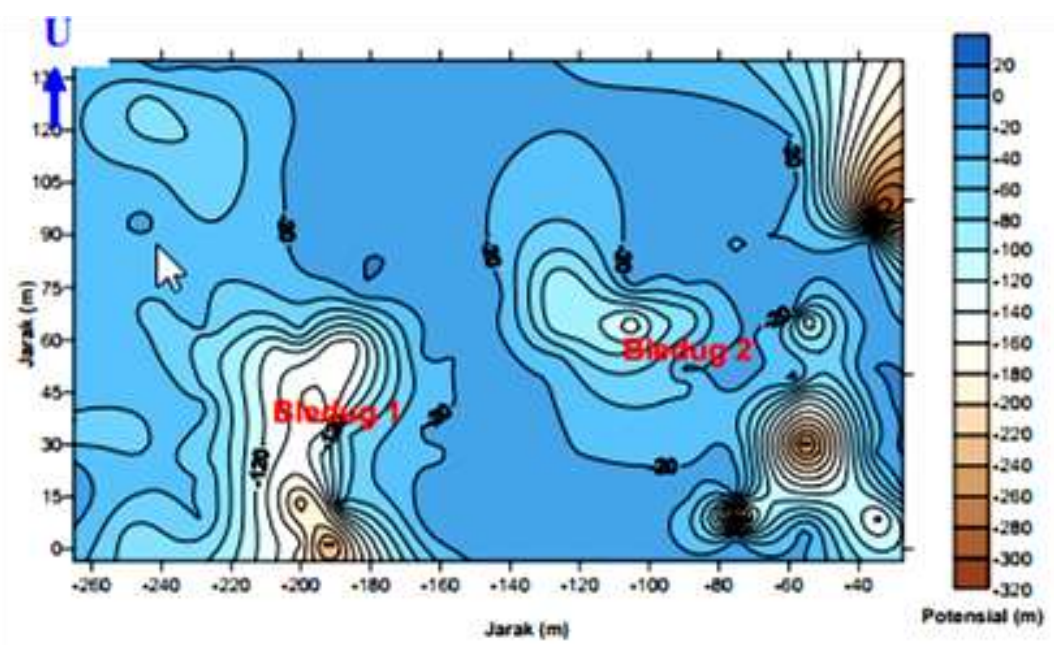

Dari profil penampang Bledug 1 (Gambar 3) dapat diamati profil yang tajam dan tidak lebar. Perhitungan nilai parameterparameter benda penyebab anomali yaitu kedalaman pusat sumber anomali dan sudut polarisasinya dilakukan dengan menggunakan nomogram (matching curve). Tampilan profil yang tajam mengindikasikan adanya sumber yang dalam. Dengan mengasumsikan bentuk benda sumber anomali adalah bola diperoleh nilai kedalaman dari permukaan ke pusat bola $23,68 \mathrm{~m}$ dan sudut polarisasi $71,38^{\circ}$. Dari Bledug ke dua ini letupan yang dihasilkan lebih jarang tetapi lebih besar. Untuk mengetahui kedalaman anomali dari sumber maka dari tampang melintang yang diambil dari Bledug kedua selanjutnya dibuat sebuah profil yang diproyeksikan ke koordinat kartesian (Gambar 3). Setelah dilakukan perhitungan, sumber anomali menyebar dengan kedalaman 40,8 meter, dan sudut polarisasi $70^{\circ}$. Untuk Bledug 3 yang terletak di sebelah tenggara Bledug 2 setelah dilakukan perhitungan (Gambar 3), sumber anomali menyebar dengan kedalaman 19,5 meter, dan sudut polarisasi $100^{\circ}$ (Indriana et al., 2007).

Berdasarkan kesimpulan hasil tersebut, peneliti menyebutkan bahwa survei potensial diri merupakan survei pendahuluan untuk mengetahui pola penyebaran anomali oleh sumber, yaitu dalam hal ini Bledug Kuwu, maka sebaiknya perlu dilakukan survei lebih lanjut untuk melengkapi hasilnya dan perlu dilakukan studi teoritik, lebih lanjut interpretasi kuantitatif data self-potential untuk model yang lain. 
Gambar 3. Profil tampang lintang Bledug dari kiri ke kanan; Bledug 1, Bledug 2, Bledug sebelah Timur (Tenggara) Bledug 2.
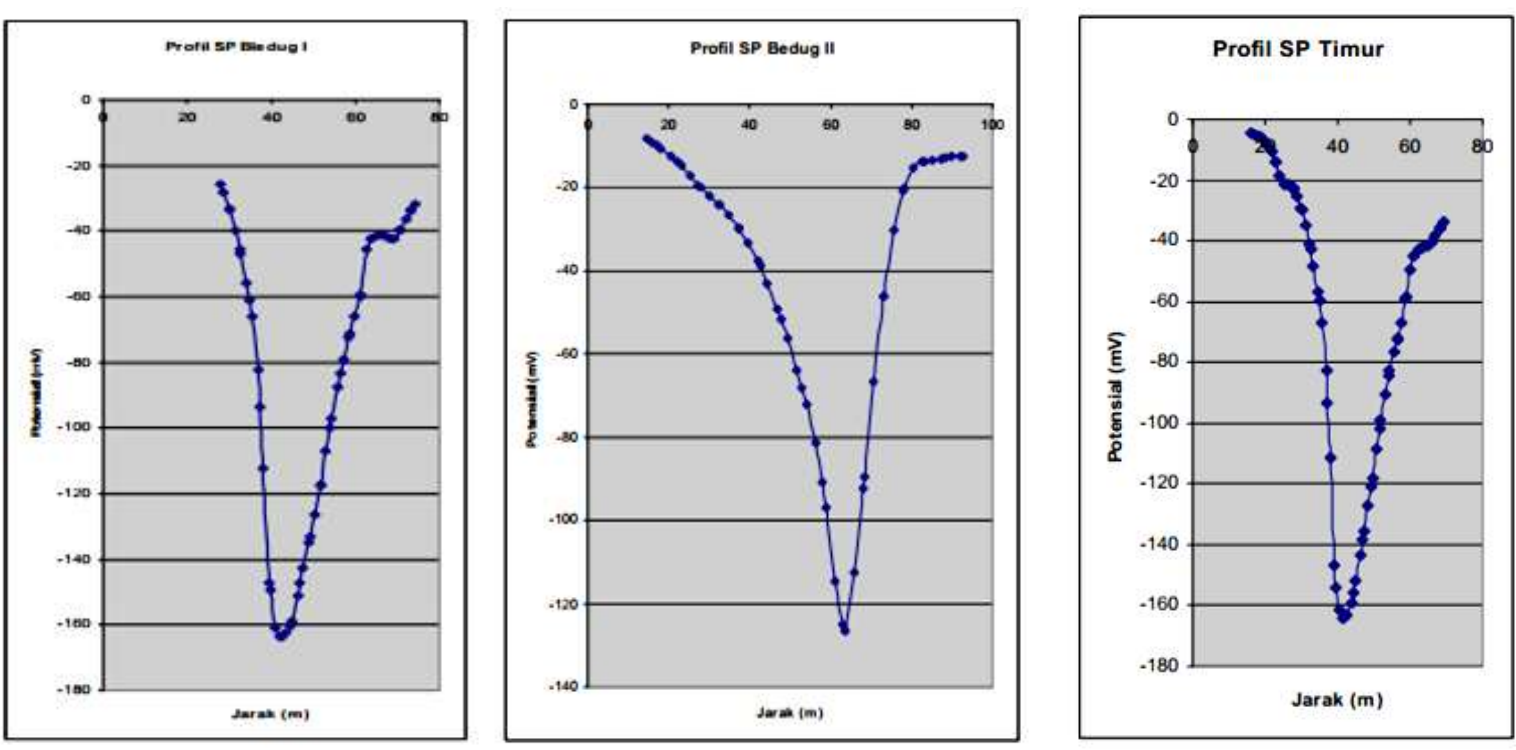

\section{5. 2. Geologi}

Keadaan

geologi

regional menunjukkan bahwa mulai dari Semarang ke arah timur hingga daerah Kuwu merupakan endapan alluvial yang termasuk zona Randublatung. Daerah ini mempunyai kenampakan morfologi datar. Di bagian utara terdapat perbukitan bergelombang lemah dan sedang. Sedangkan di bagian selatan dibatasi oleh bagian darat zona Kendeng (van Bemmelen, 1949). Di sebelah timur terdapat jalur sesar yang berarah barat-timur, yang merupakan sesar normal. Di sebelah selatan terdapat jalur sesar yang berarah barat-timur yang merupakan sesar naik, tegak lurus sesar tersebut terdapat sesar normal.

Proses terjadinya letupan dikarenakan adanya tekanan dari bawah yang mampu mendorong naik batuan yang dilaluinya. Anomali daerah Bledug Kuwu berasal dari batuan yang mengalami sesar yang memanjang dari arah Barat Daya menuju timur laut. Sesar yang terjadi akan mengakibatkan keluarnya aliran gas ke permukaan bumi melalui batuan yang mudah dilaluinya. Batuan yang terlewati harus mudah dilalui sumber tekanan. Pada prinsipnya material dari dalam bumi akan keluar ke permukaan karena di bawah permukaan bumi suhu dan tekanannya besar. Bila batuan dasarnya sangat keras maka material dengan tekanan besar ini seperti terperangkap dan tidak bisa keluar. Material dari dalam bumi ini dapat keluar jika terdapat rekahan, patahan, ataupun karena adanya aktifitas eksplorasi (van Bemmelen, 1949).

Mud vulcano terbentuk karena natural gas yang naik ke permukaan ketika menemukan konduit (sesar mendatar yang tegak) dan membawa lumpur ( $m u d$ ) yang punya densitas lebih ringan dari sedimen di sekitarnya. Lumpur, gas, batuan, belerang dan garam (di wilayah kering) serta air akan diletuskan di permukaan membentuk kerucut seperti gunung. Proses sedimentasinya dalam skala yang lebih kecil tetapi dalam gerakan yang lebih cepat, jadi dipicu oleh adanya paket sedimen berdensitas rendah dikelilingi paket sedimen berdensitas lebih tinggi. Gerakan tektonik berpengaruh, juga pada sedimen yang diendapkan. Wilayah sesar mendatar aktif merupakan lahan subur mud vulcano. Komposisi dari mud terdiri dari berbagai fase: padat, plastis, cair, dan gas membawa semua bahan-bahan batu-batu, lumpur, belerang, garam, dan gas dari dalam membentuk kolom vertikal. Banyak kondisi geologi atau geofisika semacam Bledug Kuwu di Purwodadi, di antaranya adalah di 
wilayah Yordan. Tetapi bedanya dengan Bledug Kuwu di Purwodadi adalah di Yordan keluaran dari kondisi geologi tersebut adalah gas metana, sedangkan di Purwodadi adalah material lumpur. Mud vulcano dapat terbentuk di bawah laut (sea bed). Hanya skalanya sampai ke permukaan atau tidak, akan ditentukan oleh volume bahan rombakan subsurface yang dibawanya naik (Indriana et al., 2007).

\section{5. 3. Geomatika}

Rekonstruksi spasial dari data satelit dilakukan dengan mengklusterkan digital number. Hasil rekonstruksi spasial dari pantai utara Jawa jaman purba dan gunung Muria ditandai dengan warna biru. Fase sedimentasi ditunjukkan dengan tiga fase utama yang ditandai dengan zona yang berwarna hijau, coklat dan oranye. Untuk mengetahui kebenaran sampel maka model rekonstruksi spasial dapat dibandingkan dengan peta lama De Graaf seperti Gambar 4 (Hartoko et al., 2014).

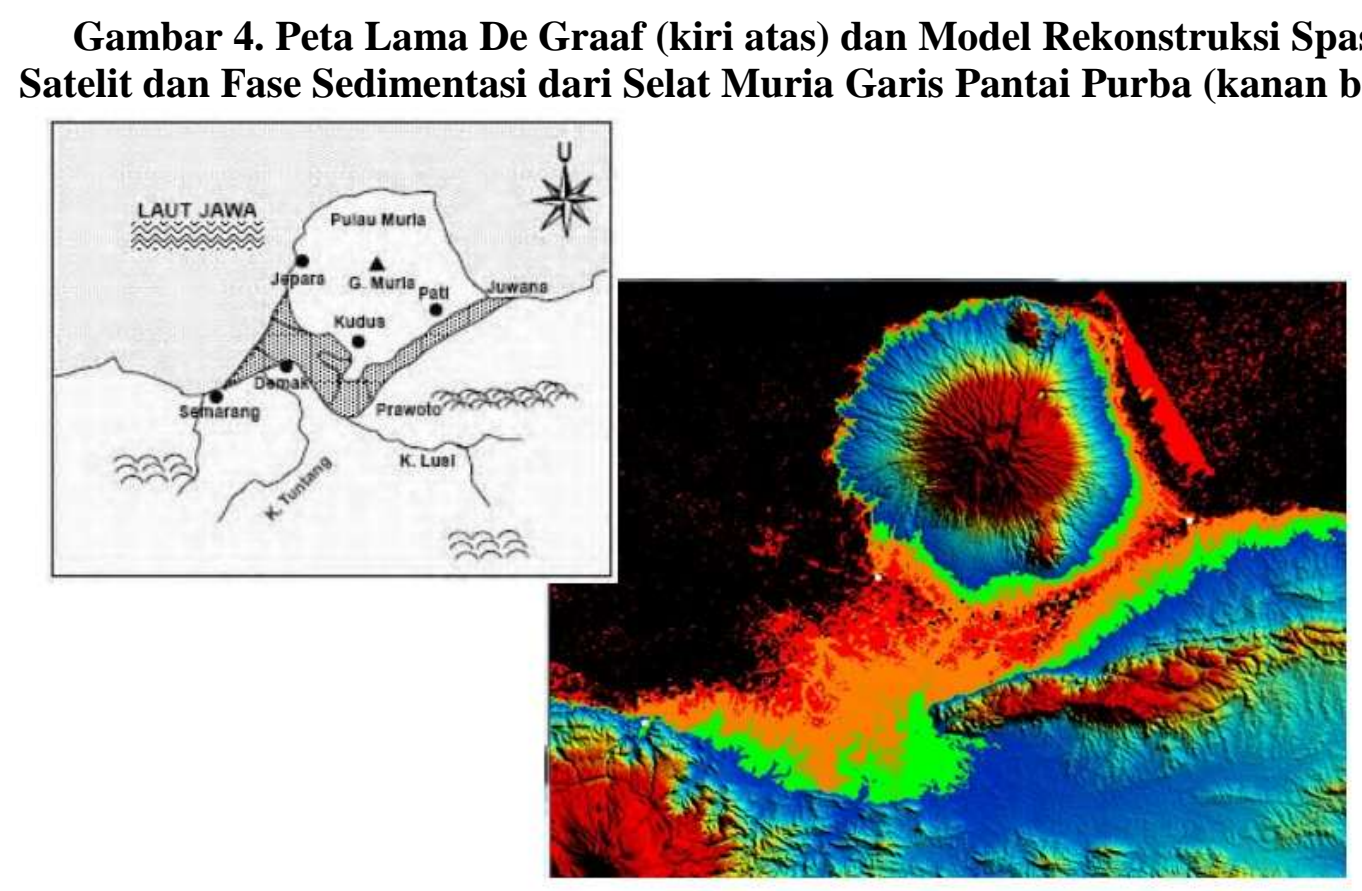

(Hartoko et al., 2014).

Secara geografis De Graaf dan Pigeaud (1985) menjelaskan bahwa Demak terletak di pantai yang memisahkan Jawa dan Gunung Muria. Sebelum abad ke 17 selat tersebut luas dan dalam sehingga banyak pedagang berlayar dengan perahu dari Semarang ke Demak dan Rembang melalui selat ini. Kedua sejarawan Belanda tersebut menggambarkan bahwa Jepara pada waktu itu merupakan pelabuhan besar di sisi barat gunung Muria, yang dikelilingi oleh tiga pulau. Setelah abad ke 17 selat Muria semakin dangkal sehingga kapal tidak dapat berlayar meskipun pada musim hujan, perahu kecil masih bisa melewati dari
Demak ke Juwana Pati. Satu-satunya sungai yang masih tersisa untuk berlayar adalah sungai Serang dengan muaranya pada pantai Jepara sampai abad ke 18, di mana perahu dapat berlayar hingga Godong (sekarang dikenal sebagai kecamatan di Kabupaten Grobogan). Lombard (1996) menjelaskan bahwa Orsoy de Flines 1940 memiliki pengamatan sistematis pada beberapa bukti di Grobogan antara Semarang dan Blora yang dibentuk oleh sedimen tersier. Lombard mengasumsikan bahwa ada air laut dari selat Muria yang terperangkap yang dikenal sebagai Bledug Kuwu (Gambar 5). 

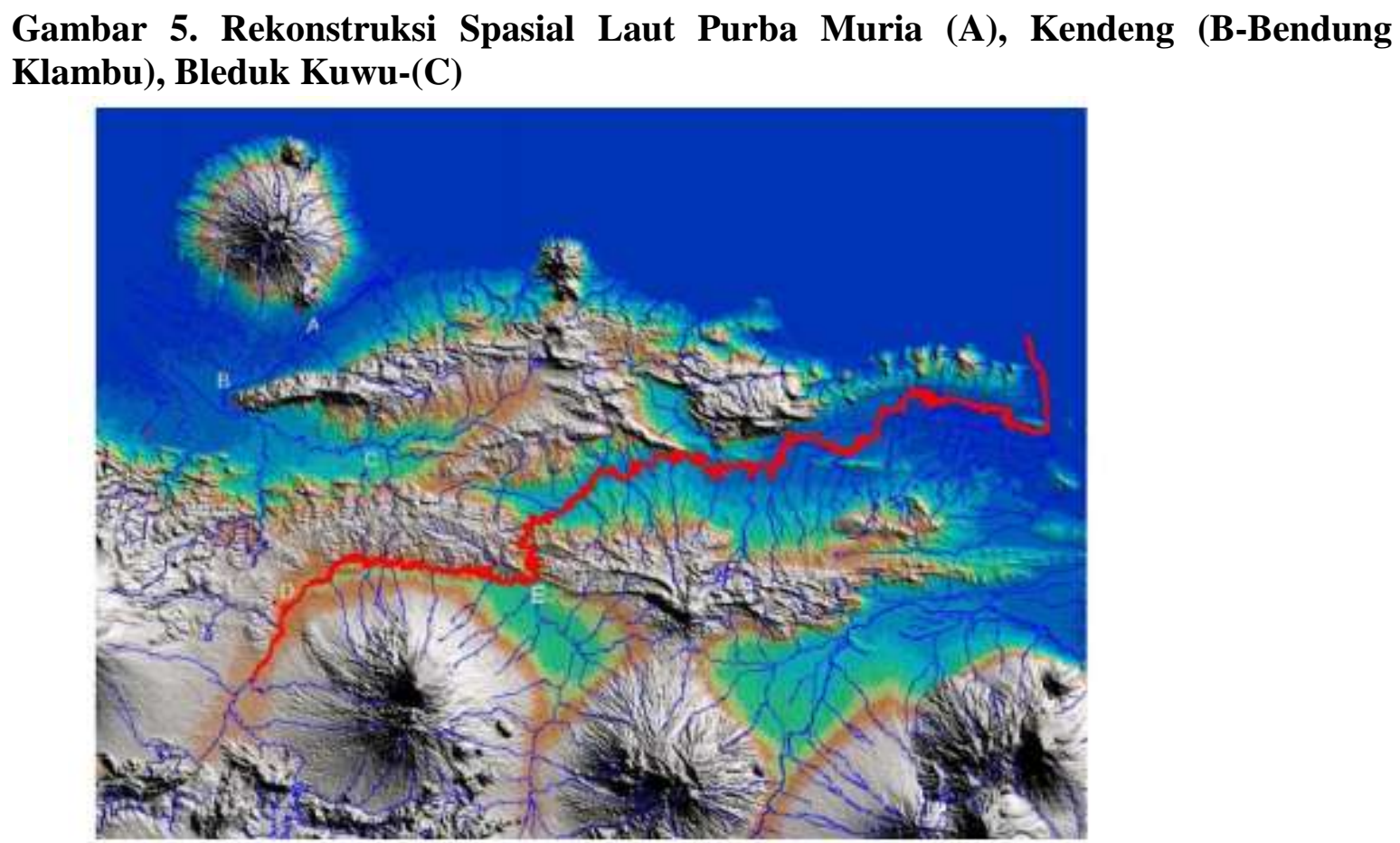

(Hartoko, 2012)

\section{5. 4. Palaentologi}

Fosil moluska yang ditemukan di Bledug Kuwu (Gambar 6) telah diidentifikasi berasal dari lingkungan laut. Bledug Kuwu secara geologi terletak dalam zona kendeng yang diinterpretasikan sebagai garis pantai purba dari selat Muria (Hartoko et al., 2014). Selain itu, terdapat dua jenis asosiasi moluska yang ditemukan yaitu Corbula-Ostrea. Kelimpahan yang lebih banyak pada Corbula socialis lalu diikuti oleh Ostrea spp., Ostrea lingula, Nucula bantamensis dan Pecten sp. Kondisi lingkungan mengandung salinitas antara 0.5$30 \%$ dengan suspensi tanah liat-batuan dan pasir halus dan proses sedimentasi yang dipengaruhi oleh pasang.

Asosiasi moluska dari Arca-Ostrea yang didominasi oleh kemunculan Arca, Ostrea, Venus dan Laevidentalium eburneum hidup pada lingkungan laut, sedangkan Tarebia sp menunjukkan hidup pada lingkungan air payau. Asosiasi moluska dari Arca-Corbula dikembangkan di atas bagian dari Horizon Moluska II pada formasi Pucangan yang menunjukkan lingkungan delta luar yang sudah dipengaruhi oleh laut, memiliki salinitas 30 \%o (Hartoko et al., 2014). 


\section{Gambar 6. Fosil Moluska di Bledug Kuwu}

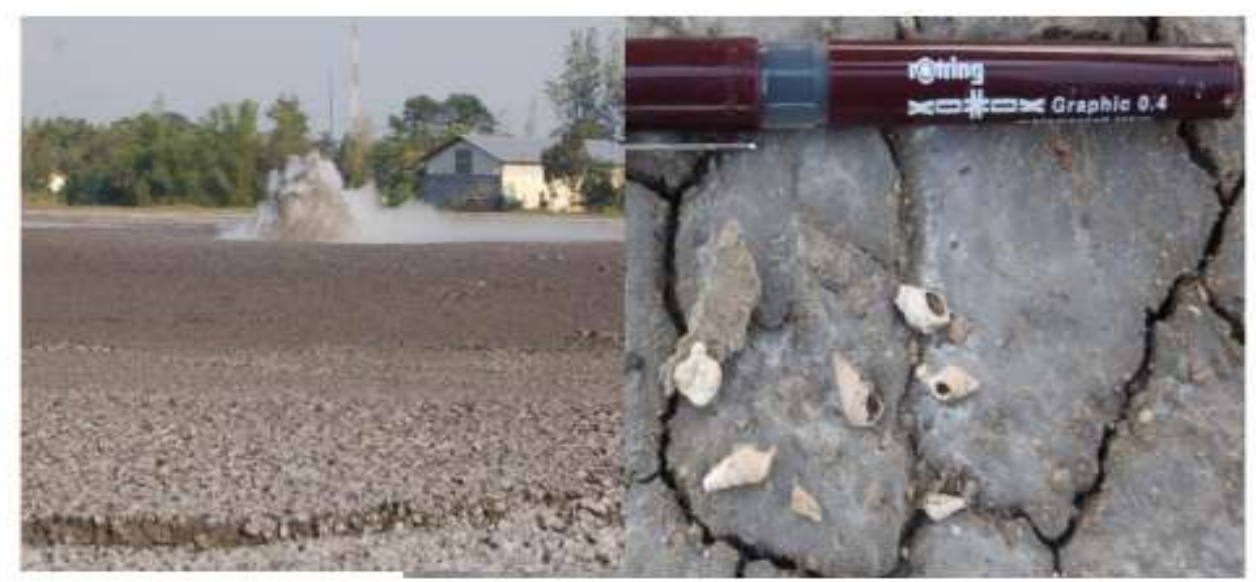

(Hartoko et al., 2014).

\section{5. 5. Mikrobiologi, Biokimia dan Molekuler}

Para mikrobiolog telah berhasil mengisolasi beberapa bakteri yang tahan terhadap salinitas tinggi (halotoleran) dari Bledug Kuwu, yaitu bakteri yang mampu hidup pada daerah berkadar garam disebut sebagai bakteri halofil. Penelitian-penelitian tersebut bertujuan untuk mengeksplorasi potensi dari masing-masing bakteri halofil sehingga penemuan-penemuan komponen bioaktifnya dapat menjadi rujukan dalam bidang industri.

Bakteri yang berhasil diisolasi di antaranya yaitu bakteri yang berdasarkan sekuens gen 16S-rRNA mirip Halobacillus litoralis yang mampu menghasilkan enzim $\alpha$-amilasedan enzim tersebut telah diisolasi, dikarakterisasi serta dikloning gen penyandinya (Pangastuti et al., 2002). Beberapa penelitian terbaru telah berhasil mengisolasi Bacillus licheniformis BK AG21 yang menghasilkan levan yang merupakan salah satu jenis polimer fruktosa, produksi optimum levan yang diperoleh dengan melakukan kultur pada media yang mengandung sukrosa dan pepton diinkubasi dengan kecepatan aerasi 150 rpm selama 24 jam pada suhu $37^{\circ} \mathrm{C}$. (Mamay et al., 2015). Eksplorasi levan juga dilakukan pada bakteri genus Halomonas dan Chromohalobacter yang berhasil diisolasi dari Bledug Kuwu, dengan hasil yang menunjukkan bahwa dari 5 isolat (Gambar 7) hanya 1 isolat yang mampu memproduksi levan pada media Belgith modifikasi yaitu Chromohalobacter japonicas BK-AB18 (Nasir et al., 2015). Biosurfaktan yang merupakan zat permukaan aktif yang disintesis oleh sel hidup dan memiliki sifat-sifat mengurangi tegangan permukaan, menstabilkan emulsi, pembentukan busa, pada umumnya tidak beracun, dan biodegradable berhasil diisolasi dari Pseudomonas stutzeri BKAB12 media Luria Bertani (LB) dengan 3\% gliserol sebagai sumber karbon dan $\mathrm{KNO}_{3}$ sebagai sumber nitrogen, diinkubasi 28 jam pada $37^{\circ} \mathrm{C}$ dengan kecepatan aerasi $150 \mathrm{rpm}$ (Putri \& Hertadi, 2015). Analisis menggunakan studi bioinformatik juga telah dilakukan pada 6 isolat bakteri halofil dari Bledug Kuwu untuk mengetahui struktur gen lipase. Berdasarkan hasil penelitian tersebut diperoleh perbedaan yang khas dari keenam isolat bakteri dibandingkan dengan gen lipase pembanding sebagai rujukan. Perbedaan ini dapat terjadi dikarenakan kondisi habitat yang unik dimana lumpur yang berkadar garam berada pada daratan dan jauh dari laut (Asy'ari et al., 2015). 
Gambar 7. Hasil skrining 5 bakteri halofilik dari genus Halomonas dan Chromohalobacter, (a) Halomonas meridian BK-AB4, (b) Halomonas elongata BK-AB8, (c) Halomonas eurihalina BK-AB15, (d) Halomonas elongata BK-AG18, dan (e) Chromohalobacter japonica BK-AB18

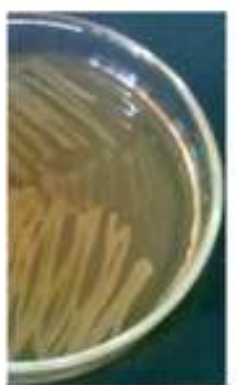

(a)

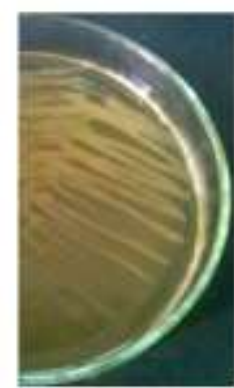

(b)

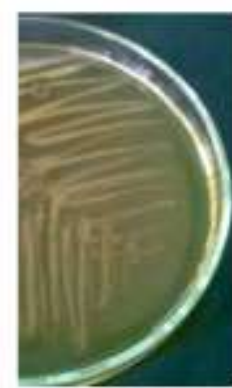

(c)

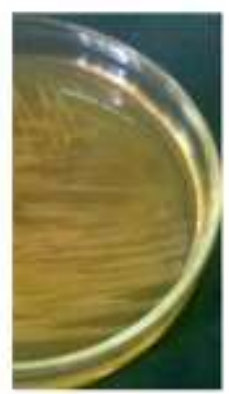

(d)

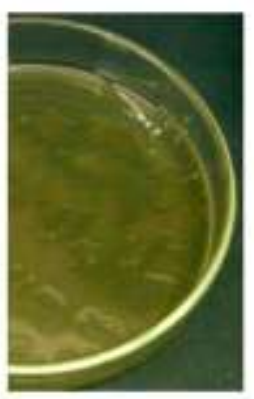

(c)

\section{5. 6. Kimia}

Bledug Kuwu mengeluarkan letupan yang mengandung gas berwarna putih dan menimbulkan aroma yang menyengat, seperti bau telur busuk. Gas yang dikeluarkan mengandung unsur sulfur/belerang. Penelitian mengenai kandungan kimia pada daerah ini belum banyak dilakukan. Berdasarkan informasi dari buku yang dicetak dan dijual pada lokasi, gas yang dikeluarkan adalah $\mathrm{H}_{2} \mathrm{~S}$. Selain gas hidrogen sulfida juga mengandung gas karbon dioksida, karena ketika uap dimasukkan ke dalam air kapur, air tersebut menjadi keruh. Reaksi kimia yang terjadi adalah sebagai berikut.

$\mathrm{Ca}(\mathrm{OH})_{2}+\mathrm{CO}_{2} \rightarrow \mathrm{CaCO}_{3}+\mathrm{H}_{2} \mathrm{O}$

Kandungan $\mathrm{CO}_{2}$ ini dapat diketahui dengan cara memasukkan bara api ke dalam gelas yang diisi dengan gas atau uap dari Bledug, seketika bara akan mati.

Sifat gas $\mathrm{CO}_{2}$ tidak mudah menyebar, hal ini menyebabkan adanya pantangan untuk memasuki area Bledug Kuwu pada pukul 19.00-07.00 WIB, karena gas $\mathrm{CO}_{2}$ pada jam tersebut konsentrasinya tinggi dan dapat mematikan (Anonim, 2015).

\section{Simpulan}

Berdasarkan uraian di atas diperoleh kesimpulan bahwa Bledug Kuwu merupakan sebuah fenomena alam unik yang ditemukan di Desa Kuwu, Kecamatan Kradenan, Kabupaten Grobogan Jawa Tengah. Secara mitologi, daerah ini masih dikaitkan dengan Laut Selatan serta masih kuat unsur tradisinya berupa ritual atau tirakatan pada waktu tertentu. Secara keilmuan, Bledug Kuwu merupakan air laut yang terperangkap dari Selat Muria, dibuktikan dengan adanya fosil moluska yang hidup pada lingkungan berkadar garam tinggi. Metode potensial diri mendukung informasi dalam hal anomali daerah Bledug Kuwu, bahwa daerah ini berasal dari batuan yang mengalami sesar yang mengakibatkan keluarnya aliran gas ke permukaan bumi melalui batuan yang mudah dilaluinya. Bila batuan dasarnya sangat keras maka material dengan tekanan besar ini seperti terperangkap dan tidak bisa keluar. Secara kimia, kawasan ini mengandung gas beracun berupa $\mathrm{H}_{2} \mathrm{~S}$ dan gas yang dapat mematikan jika konsentrasinya berlebih seperti $\mathrm{CO}_{2}$. Bakteri-bakteri potensial juga telah berhasil diisolasi dari kawasan Bledug Kuwu untuk menghasilkan enzim yang dapat dikembangkan untuk dunia industri sehingga dengan perkembangan ilmu pengetahuan suatu fenomena alam dapat dikaji lebih jauh, baik untuk mengetahui asal-usulnya maupun diambil manfaatnya untuk kesejahteraan manusia.

\section{Daftar Pustaka}

\author{
Admin1. 2011. Kabupaten Grobogan di \\ Awal Sejarah. \\ http://grobogan.go.id/profil/sejarah. \\ Diakses 8 Januari 2016.
}


2015. Karakteristik Wilayah. http://grobogan.go.id/profil//kondisigeografi/karakteristik-wilayah. Diakses 8 Januari 2016.

Anonim. 2015. Legenda Terjadinya Bledug Kuwu. Kuwu: Bledug Kuwu Press.

Asy'ari M, Aditiawati P, Akhmaloka and Hertadi R. 2015. "Structural Analysis of Halophilic Lipases Isolated from Bledug Kuwu Mud Crater, Purwodadi, Grobogan, Indonesia: a Structural Bioinformatics Study." Procedia Chemistry. 16: 392-399.

De Graaf, H. J. and Th. G. Pigeaud. 1985. Kerajaan-Kerajaan Islam di Jawa: Peralihan Dari Majapahit ke Mataram. Jakarta: Grafiti Pers.

Giwangkara, E. G. 2006. Mud Volkano Kuwu (Bledug Kuwu). https://persembahanku.wordpress.com /2006/10/01/mud-volkano-kuwu-

bledug-kuwu/. Diakses 8 Januari 2016.

Hartoko, A. 2012. Spatial Algorithms Developments for the Reconstruction of Ancient Seas of Java. Lecture Material: Master Program, Coastal Resources Management. Semarang: Diponegoro University.

Hariyadi, Suhardjo P, Srisumantyo I. T. 2014. Satellite Data Spatial Based Reconstruction and Discovery of the Ancient Coastaline, Coral-Fringing Reef and Mollusc Fossils at the Muria Strait, Central Java, Indonesia. Proceeding 6th Indonesia Japan Joint Scientific Symposium. ISBN:978-979-8786-525.

Indriana, R. D, Nurdwiyanto M. I., Haryono K. W. 2007. Interpretasi Bawah Permukaan dengan Metode Self Potential Daerah Bledug Kuwu Kradenan Grobogan. Berkala Fisika. 10(3): 155-167.

Lombard, D. 1996. Nusa Jawa: Silang Budaya, Kajian Sejarah Terpadu. Jakarta: Gramedia.
Nasir, D. Q., Wahyuningrum D, Hertadi R. 2015. Screening and Characterization of Levan Secreted by Halophilic Bacterium of Halomonas and Chromohalobacter Genuses Originated from Bledug Kuwu Mud Crater. Procedia Chemistry.16: 272-278.

Pangastuti, A., D. Wahjuningrum \& A. Suwanto. 2002. "Isolasi, Karakterisasi, dan Kloning Gen Penyandi $\alpha$-Amilase Bakteri Halofil Moderat asal Bledug Kuwu." Hayati, 9 (1): 10-14.

Putri, M and Hertadi R. 2015. Effect of Glycerol as Carbon Source for Biosurfactant Production by Halophilic Bacteria Pseudomonas stutzeri BK-AB12. Procedia Chemistry, 16: 321-327.

Raffles, Sir Thomas Stamford. Vol. I, 1817; Vol. II, 1830. The History of Java. London: John Murray, Albemarle Street.

Soekanto. 1958. Peristiwa-peristiwa Sedjarah, termasuk cultuurstelsel dan hukum adat. Makasar: Saksama.

Sugiyo. 2015. Narasumber merupakan Juru Kunci Bledug Kuwu sejak tahun 1962. Wawancara dilakukan pada tanggal 1 Januari 2016.15:30 WIB.

Van Bemmelen, R. W. 1949. The Geology of Indonesia: General Geology of Indonesia and Adjacent Archipelagoes. The Hague, Batavia: Government Printing: Batavia. 